\title{
Is There a Need to Mitigate the Social and Financial Consequences of Tuberculosis at the Individual and Household Level?
}

\author{
Nils Grede $\cdot$ Joan M. Claros $\cdot$ Saskia de Pee $\cdot$ \\ Martin Bloem
}

Published online: 8 April 2014

(c) Springer Science+Business Media New York 2014

\begin{abstract}
This paper reviews evidence on social and economic costs of tuberculosis. Key socio-economic consequences include stigma, social isolation, increased outof-pocket expenditures for medical and non-medical costs and reduced income. Many of the financing methods that households use have long-term negative impacts and the poor are most vulnerable to these costs. Together, these negative consequences adversely affect TB control, in terms of delayed diagnosis, delayed initiation of treatment, suboptimal adherence and failure to complete treatment, as well as the coping and well being of the individual and household. There are two ways to reduce treatment costs for the patient; one can either reduce the direct and indirect costs of seeking a diagnosis and obtaining treatment and/or provide income transfers to offset some of those costs incurred. Social transfers in the form of food, cash or vouchers can mitigate the negative effects by enabling the individual to seek a diagnosis, protecting minimum food expenditures, reducing the need to accumulate debt and reduce productive assets and reducing the negative impacts on other household members, particularly young children and school-age children.
\end{abstract}

Keywords Social transfers $\cdot$ TB $\cdot$ Socioeconomic consequences $\cdot$ Household expenditure $\cdot$ Coping strategies

N. Grede $(\bowtie) \cdot$ J. M. Claros $\cdot$ S. de Pee $\cdot$ M. Bloem Nutrition and HIV/AIDS Policy, Policy and Strategy Division, World Food Programme, Via. G. Viola 68, Parco dei Medici, 00148 Rome, Italy

e-mail: nils.grede@wfp.org

\section{Background}

The socioeconomic consequences of tuberculosis can be devastating for the individual, household and community. The heavy burden of tuberculosis [1], is part of the broader economic burden ${ }^{1}$ of illness for households in low-resource settings. Health care costs are distributed very unevenly, with most of the population incurring none in any given period in time, while a very small minority can face significant expenditures well beyond its means. A study in Indonesia showed that $10 \%$ of the spenders accounted for $80 \%$ of the expenditure resulting in a GINI coefficient for health expenditures of 0.88 [3]. One review of the economic costs and consequences of illness for households, focusing on malaria, tuberculosis and HIV/AIDS, found that illness imposed high and regressive ${ }^{2}$ cost burdens on patients and their families [2]. Another review found that total TB costs to the patient, both direct and indirect, in Ghana, Vietnam and the Dominican Republic, summed up to approximately 1 year of individual income in all three countries [4].

For some analysts an expenditure of $10 \%$ of monthly household income on health care expenditure is considered catastrophic, with the term catastrophic implying that such expenditure levels are "likely to force households to cut their consumption of other minimum needs, trigger productive asset sales or high levels of debt and lead to impoverishment" ${ }^{3}[2,3,5,6]$. Other analysts including

\footnotetext{
${ }^{1}$ Cost burden is defined as direct or indirect costs expressed as a percentage of household income [2].

${ }^{2}$ Costs are defined as regressive when they impose a greater burden on poor families than better-off families, that is, spending is a higher proportion of income [2].

${ }^{3}$ Impoverishment may be defined as processes of household asset depletion and income loss that cause consumption levels to fall below minimum needs.
} 
WHO have defined treatment costs as 'catastrophic' when out-of-pocket payment equals or exceeds $40 \%$ of household capacity to pay [7].

The definition of 'catastrophic' should include not only the percentage of income, but also the length of the period over which the additional expenditure is needed as well as take into account the socio-economic status of the household or in other words its ability to cope with a sustained period of higher expenditure. Prescott has shown that poor households face catastrophic expenditures far less often, likely because they can simply not afford medical care when facing serious disease episodes [3]. A sustained $10 \%$ of income can be catastrophic if a household already lives below the poverty line and is already failing to meet its health, education and dietary needs. $40 \%$ may not be always catastrophic if a household has savings and if the expenditure is incurred over a short period of time. As income is often irregular for poor households and diseaseinduced costs often have sudden peaks, matching income and expenditure becomes all the more difficult in the absence of savings or asset cushions. However one defines 'catastrophic', poor households that are already experiencing food insecurity may be pushed even deeper into poverty and food insecurity by the cost of disease and of its treatment, with adverse consequences for both the individual and vulnerable family members, especially young children [1, 8-10].

The inescapable association between poverty and tuberculosis, and the tendency for the disease to lead to further impoverishment of already poor households, undermining care-seeking behaviour and treatment completion rates and outcomes, mean that it is vital for TB programmes to provide the necessary patient support to facilitate early diagnosis and treatment completion.

Reductions of the cost burden can be made in different ways and one can typically distinguish between supply and demand side focused mechanisms. Supply side mechanisms attempt to lower or eliminate the cost of care, making care available and affordable. They ensure that services are available at most health care facilities, that patients do not have to pay for registration or visits to the facility, that the treatment protocols are simplified and modern diagnostics reduce the number of necessary visits to diagnose TB, and that TB treatment is for free. Demand side mechanisms often consist of transfers to affected patients to help them meet the temporary additional expenditure. They support patients dealing with reduced income and increased expenses, which is a common situation even when medical care itself is free. Such transfers, often in the form of cash, vouchers or food, are usually made in the context of regular patient visits to the TB clinic or healthcare facility for check-ups and collection of medications and are part of a wider social protection approach designed to prevent deterioration in health status, protect from destitution and catastrophic losses of human capital, and promote improved livelihood opportunities. Often conditionality is attached to receiving the transfer, such as regular attendance of medical appointments. While many developed and developing country governments provide such transfers, the World Food Programme is probably the single biggest global provider, having reached 360,000 TB patients and their household members through its food assistance ${ }^{4}$ programmes in over ten countries in 2012. In the top ten countries alone, 91,000 index clients were reached while support was also given to an additional 248,000 household members. The biggest recipient countries were Afghanistan, Somalia, South Sudan, Tajikistan and Haiti [11]. Household members are often included for a variety of reasons: the economic burden of disease falls on the household, while household members may also be at high risk of infection.

Food assistance, whether provided as an in-kind food transfer, cash or a food voucher, is a social transfer. Its effectiveness to mitigate ${ }^{5}$ the severe social and economic consequences of tuberculosis is assumed to lie in its value as an income transfer for cash-strapped poor households that enables desired behaviours (for example proper adherence to treatment), offsets the heavy costs associated with diagnosing tuberculosis and obtaining treatment, and minimizes potential negative coping strategies. The deeper the poverty and food insecurity of TB-affected households, the greater the potential impact of a basic package of monthly food support or the equivalent in cash or vouchers.

The objective of this paper is to review the evidence on: (i) the negative social consequences, experienced by individuals with tuberculosis, especially in resource-limited contexts; (ii) the direct and indirect financial costs; (iii) the link between illness financing methods and coping strategies; and (iv) to discuss the potential role of social transfers in mitigating these real financial hardships and minimizing negative coping strategies.

\footnotetext{
${ }^{4}$ Food assistance is defined as "the set of interventions designed to provide access to food to vulnerable and food insecure populations. Included in the definition are instruments, such as in-kind food, voucher or cash transfers, to assure access to food of a given quantity, quality or value. These instruments can be used to pursue specific objectives, such as nutrition, education or disaster risk reduction." This definition is the one used by the World Food Programme, the world's largest humanitarian organization, which supports annually over two million people affected by HIV and TB.

${ }^{5}$ For the purpose of this paper 'to mitigate' is defined as 'to make (something bad) less severe, serious or painful' (Source: Oxford Dictionaries online: http://oxforddictionaries.com/definition/mitigate).
} 


\section{Methodology}

A literature search was conducted to identify published quantitative or qualitative intervention studies, both peerreviewed and grey literature, assessing the mitigation value of social transfers among poor, TB-affected individuals and households in low-income contexts. We used Google Scholar and a Boolean table with the following strings and operators (and variations thereof): (mitigation OR mitigate) AND (food OR cash OR voucher OR food assistance OR transfer) AND (tuberculosis OR TB OR illness) AND (cost OR burden OR social consequences OR economic consequences OR socio-economic consequences OR impact). The titles and/or the abstracts of studies found in the first ten pages of the Google search yield were analysed to determine whether they described or analysed the mitigation value of social transfers or vouchers in the context of tuberculosis.

As intervention studies could not be identified using the above search strategy, we decided to include studies that assessed the cost burden of illness, particularly tuberculosis, since such studies provide the basis or rationale for the provision of social transfers designed to mitigate the social and economic consequences of illness among the poor.
Studies on the burden of illness were identified using Google Scholar and a Boolean table with the following strings and operators (and variations thereof): (impact OR consequences OR hardship OR burden OR cost) AND (financial OR social OR economic OR socio-economic OR food security) AND (tuberculosis OR TB OR DOT OR DOTS) AND (individual OR household OR community). The titles and/or the abstracts of studies found in the first ten pages of the Google search yield were selected if they provided information and insights into the social and economic consequences of tuberculosis. Additional studies were identified in the reference section of selected studies and review papers and through researcher colleagues.

\section{Findings}

\section{The Social Consequences of Tuberculosis}

The negative social impact of TB extends beyond the TB patient to household members and the larger community (see Table 1).

Gelaw et al. [12] find that stigmatisation and social exclusion of TB patients are fuelled by the failure of the

Table 1 Key findings on the social costs of TB from selected studies

\begin{tabular}{|c|c|c|c|}
\hline & Setting & Design & Social consequences of TB \\
\hline Gelaw et al. [12] & $\begin{array}{l}\text { Addis Ababa, } \\
\text { Ethiopia }\end{array}$ & $\begin{array}{l}\text { Cross-sectional survey } \\
\text { (questionnaire and focus } \\
\text { group discussion, }(n=703 \\
\text { and } n=36 \text { respectively) }\end{array}$ & $\begin{array}{l}69 \% \text { feel that TB patients are not accepted in the community } \\
\text { and } 78.3 \% \text { fear physical contact with TB patients. Most think } \\
\text { that TB is associated with HIV/AIDS. The social } \\
\text { consequences of these attitudes are stigmatization and social } \\
\text { exclusion }\end{array}$ \\
\hline Liefooghe et al. [13] & Sialkot, Pakistan & $\begin{array}{l}\text { Focus group discussions } N=6 \\
\text { focus groups } N=48 \mathrm{~TB} \\
\text { patients }\end{array}$ & $\begin{array}{l}\text { TB is perceived as a very dangerous, infectious and incurable } \\
\text { disease. This perception has many social consequences: } \\
\text { stigmatization and social isolation of TB patients and their } \\
\text { families; diminished marriage prospects for young TB } \\
\text { patients, and even for their family members. TB in one of the } \\
\text { partners may lead to divorce. Due to fear patients often deny } \\
\text { the diagnosis and reject the treatment }\end{array}$ \\
\hline Long et al. [14] & Vietnam & $\begin{array}{l}\text { Focus group discussions } \\
N=16 \text { focus groups }(8-10 \\
\text { individuals per group) }\end{array}$ & $\begin{array}{l}\text { Male patients often worried about economic problems, while } \\
\text { female patients worried about social consequences of the } \\
\text { disease. Both in the family and the community, isolation } \\
\text { could be subtle, but it could also be obvious and had a } \\
\text { tendency to continue much longer than medically justified }\end{array}$ \\
\hline Rajeswari et al. [16] & India & $\begin{array}{l}\text { Focus group discussions and } \\
\text { interviews ( } n=304 \text { patients, } \\
n=17 \text { focus groups) }\end{array}$ & $\begin{array}{l}34 \% \text { of patients reported that due to loss of income they could } \\
\text { not afford to buy adequate food or clothing or books for their } \\
\text { children. } 11 \% \text { of children of TB patients }(n=276) \\
\text { discontinued school as a result of burden caused by parent's } \\
\text { illness ( } 8 \% \text { rural vs. } 13 \% \text { urban, } P<0.05) .8 \% \text { of children } \\
\text { took up employment to support the family }\end{array}$ \\
\hline Sengupta et al. [15] & Southern Thailand & $\begin{array}{l}\text { Focus groups }(n=10) \text { and } \\
\text { individual interviews }(n=7)\end{array}$ & $\begin{array}{l}\text { Responses informed two conceptual frameworks on stigma and } \\
\text { social support. The first model dichotomized the meaning of } \\
\text { TB into 'good' and 'bad' factors related to social support and } \\
\text { stigma, respectively. The second model identified three } \\
\text { themes - disease severity, religion, and knowledge on TB- } \\
\text { linked to stigma, social support or both }\end{array}$ \\
\hline
\end{tabular}


community to accept the disease, fear of physical contact with the individual and the perceived association with HIV and AIDS. Liefooghe et al. [13] found that the perception of TB as a very dangerous, infectious and incurable disease led to the stigmatization and social isolation of TB patients and their families and diminished marriage prospects for young TB patients, and even for their family members. Long et al. [14] also identified isolation both in the family and the community as one of the negative social consequences of the disease and found that it had a tendency to continue much longer than possibly medically justified. Sengupta et al. [15] identified three themes, namely, disease severity, religion and knowledge of $\mathrm{TB}$ - as either linked to stigma, social support or both.

The negative social consequences of tuberculosis, however, go beyond stigmatization and social exclusion or isolation. At the household level, TB has a considerable impact not only in terms of income, but also in terms of health, education and nutrition, especially if the patient is a wage earner. When the patients are female, children are at additional risk as these women may be unable to care for their children or perform routine household tasks. Rajeswari et al. [16] found that before their illness $79 \%$ of females carried out household activities, including cooking, cleaning, washing and serving food, but only $38 \%$ carried out such activities during their illness. Similarly, childcare decreased from 69 to $34 \%$. These figures indicate that tuberculosis in women affects family welfare. Further, when children are obliged to take up employment to support their families, their education suffers. The same authors found that $11 \%$ of children of TB patients had discontinued school as a result of the burden caused by a parent's illness and that $8 \%$ of children took up employment to support the family [16]. The nutritional status (and health) of children also suffers when patients can no longer afford to buy adequate food for them and have lower capacity to care for them, which may also affect the time spent on food preparation and feeding. This would seem particularly relevant in the context of the first 1,000 days between conception and the second birthday, where even a period of six months during which a child does not have access to an adequate diet, may result in irreversible stunted growth with its long term consequences for education, health and productivity [17]. Given the length of TB treatment, such occurrences can be considered likely.

\section{The Economic Consequences of Tuberculosis}

Early studies on the economics of tuberculosis control generally focused on provider costs for different intervention strategies or on the evaluation of cost-effectiveness ratios, and did not consider the issue of patient costs [1823]. There is some evidence, however, that the costs incurred by the patient may actually exceed those incurred by the health care provider [24]. The economic burden of tuberculosis includes the direct (medical and non-medical) costs and indirect costs (opportunity cost or loss of productive time usually associated with reduced income) associated with seeking diagnosis and undergoing treatment. The economic burden is also linked to the available health care financing strategies, especially those that place too much emphasis on out-of-pocket payments, and the extent to which the patient must resort to negative or unsustainable coping strategies to seek and obtain treatment (Table 2). The preferred unit of analysis for assessing the costs of illness is the household because treatment decisions and coping mechanisms are based on household negotiations, illness costs are incurred by caregivers, ${ }^{6}$ as well as the patient, and costs fall on the household budget $[25,26]$.

\section{Direct Costs and Indirect Costs}

It is important to put the cost of tuberculosis in the overall context of costs due to all illness. The review by Russell [2], which considered four categories of illness, namely, acute or moderate illness, recurring illness such as malaria, chronic and long-term illness such as TB, and terminal and steadily deteriorating health, found that in most illness studies mean direct costs of illness were estimated to be between 2.5 and $7.0 \%$ of household annual income. ${ }^{7}$ For direct costs incurred by TB alone the equivalent cost burden percentage was from 8 to $20 \%$ of annual income, with mean household expenditure on the illness, over the treatment period of 6-12 months, ranging from USD 50 to more than USD 100 [2]. Mauch et al. [4] found that direct costs incl. pre-diagnosis amounted to 2.3 months of predisease monthly individual income in Ghana. For Vietnam, this figure stood at 2.1 months. Within the direct costs, additional food expense represented between $16 \%$ in Ghana and Dominican Republic and $30 \%$ in Vietnam. During hospitalization TB patients and their accompanying family members face higher cost for food than when at home. Also the increased nutritional requirements of a TB patient mean that the cost of his/her diet may increase. The key findings on direct and indirect costs of selected TB studies are summarized in Table 3.

In terms of the proportions spent on medical and nonmedical direct costs, Russell [2] found that these proportions varied, depending on a number of demand-side

\footnotetext{
${ }^{6}$ Caregivers may or may not be part of the immediate household and are often part of the extended family.

${ }^{7}$ In the analysis of the studies covering the four illness categories some expressed the direct household cost as a monthly figure, while others gave a yearly figure.
} 
Table 2 Summary of types of economic costs and financing methods

\begin{tabular}{|c|c|c|c|c|}
\hline & \multicolumn{2}{|l|}{ Direct costs } & \multirow[t]{2}{*}{ Indirect costs } & \multirow[t]{2}{*}{ Financing methods } \\
\hline & Medical costs & Non-medical costs & & \\
\hline Individual & $\begin{array}{l}\text { Drugs e.g. TB } \\
\text { medicines Hospital } \\
\text { fees e.g. laboratory } \\
\text { tests, doctor fees, } \\
\text { examinations }\end{array}$ & $\begin{array}{l}\text { Transportation, } \\
\text { Paramedical interventions, } \\
\text { Food during hospital visits, } \\
\text { Nutritious foods, } \\
\text { Lodging }\end{array}$ & $\begin{array}{l}\text { Income reduction due to partial or } \\
\text { complete inability to work } \\
\text { Decreased earning ability due to } \\
\text { illness } \\
\text { Long-term disability requiring a } \\
\text { change in type of work }\end{array}$ & $\begin{array}{l}\text { Out-of-pocket payments } \\
\text { Bank loans } \\
\text { Sale of household assets } \\
\text { Transfer payments from private } \\
\text { sources other than patients' } \\
\text { household members }\end{array}$ \\
\hline $\begin{array}{l}\text { Household and/ } \\
\text { or caregiver }\end{array}$ & & $\begin{array}{l}\text { Transportation, Food } \\
\text { during hospital visits, } \\
\text { Lodging }\end{array}$ & $\begin{array}{l}\text { Income reduction due to partial or } \\
\text { complete inability to work }\end{array}$ & $\begin{array}{l}\text { Reduced expenditure on other } \\
\text { costs } \\
\text { Labour substitution to maintain } \\
\text { or increase income }\end{array}$ \\
\hline
\end{tabular}

Financing strategies will be discussed in further detail in connection with coping strategies

factors, including preferences for special foods and supplyside factors such as service availability, distance and user fee policy. Mauch et al. [4] found that usually medical costs dominated within the direct cost category. While TB medication and treatment is often free, non-TB medication and exams often represent a substantial portion of the prediagnosis and diagnosis direct cost, while hospitalization consumes the lion share of direct treatment cost.

Context likely influences the relative share of medical versus non-medical costs. This includes factors such as what medical services are offered for free, user fees, insurance coverage, but also distance from the clinic. There is substantial evidence to show that the direct costs of illness are regressive and impose a heavier burden on poor families than on better-off families [2]. It can be assumed that this tendency also holds true for total patient costs. While the poor in general spend less on illness treatment than other income groups, the spending represents a higher proportion of income. Russell [2] identified regressive cost burdens in India, China, Thailand, Vietnam, and Sierra Leone. In addition, two TB studies from rural China and Malawi, which stratified analysis by income group, also found regressive cost burdens [27, 28].

Indirect costs, caused by the loss of productive labour time due to illness, mean that the household's capacity to earn income is reduced at a time when additional funds are required to pay for treatment. Indirect disease costs can be much higher than direct costs. Mauch et al. [4] found that between $27 \%$ (in Vietnam), 60 \% (in Dominican Republic) and $70 \%$ (in Ghana) of patients had to stop working for at least a period of time resulting in income loss. In all three countries, about a third of patients required hospitalization at some stage. They also found that $73 \%$ (in Ghana), $84 \%$ (in Vietnam) and $88 \%$ (in Dominican Republic) of total patient costs per episode of TB were indirect [4].

These indirect costs are greater for tuberculosis than for malaria, for example, because of the long duration of treatment, long delays before proper diagnosis, and its prevalence among the economically active population. Stigma may also contribute to increasing indirect costs, as people may stay away from work and social contacts for longer than strictly required for medical reasons. Russell [2] found that the total costs of TB represented catastrophic proportions of household income in already poor settings. The financial hardship that many poor people face is likely to deter them from seeking treatment [29]. One study in Vietnam found that poor people needed to work and could not afford to seek TB diagnosis and treatment for fear of losing income and possibly their jobs [30].

In the study by Kemp et al. [31] the poor faced direct and indirect costs of US\$15 compared to US $\$ 48$ faced by the non-poor in accessing a TB diagnosis; however, the poor spent $244 \%$ of their total monthly income on TB diagnosis compared with $129 \%$ for the non-poor. Relative to total income, therefore, the poor were twice as much affected as the non-poor, which makes the need to identify strategies for diagnosing TB that are cost-effective for the poor and their households evident [31].

If income available after expenditure on food is taken into account, then the impact of seeking a TB diagnosis is worse. In the study by Kemp et al. [31] it was found that the poor in Lilongwe spend $57.5 \%$ of their income on food, whereas the non-poor spend only $29.8 \%$. This meant that seeking a TB diagnosis cost the poor $574 \%$ of their available non-food monthly income compared to $184 \%$ for the non-poor [31].

\section{Financing Methods and Coping Strategies}

One must go beyond direct and indirect treatment costs in order to understand fully the economic impact of tuberculosis on households. It is also important to investigate how poor patients are forced to finance the cost of diagnosing and treating tuberculosis because this directly 
Table 3 Summary of key findings on direct and indirect costs from selected TB studies

\begin{tabular}{|c|c|c|c|}
\hline & Setting & Design & Key findings on direct and indirect costs \\
\hline Jackson et al. [27] & Rural China & $\begin{array}{l}\text { Case-control and case } \\
\text { follow-up study ( } n=160 \\
\text { cases, } n=320 \text { controls })\end{array}$ & $\begin{array}{l}\text { Direct out-of-pocket treatment costs (medical and non-medical) } \\
\text { accounted for } 55.5 \% \text { of average annual household income } \\
\text { (excluding income losses); most TB cases fell into heavy debt }\end{array}$ \\
\hline $\begin{array}{l}\text { Kamolratanakul } \\
\text { et al. [20] }\end{array}$ & Thailand & $\begin{array}{l}\text { Cross-sectional survey } \\
\quad(n=673 \text { total, } n=153 \\
\text { below poverty line })\end{array}$ & $\begin{array}{l}\text { For patients with incomes below the poverty line, average out-of- } \\
\text { pocket expenditures for TB amounted to more than } 15 \% \text { of } \\
\text { annual household income, while incomes were reduced } 5 \% \text { due } \\
\text { to illness-related effects }\end{array}$ \\
\hline Kemp et al. [31] & $\begin{array}{l}\text { Urban Lilongwe, } \\
\text { Malawi }\end{array}$ & Survey $(n=179)$ & $\begin{array}{l}\text { On average, patients spent USD } 13 \text { (MK } 996 \text { or } 18 \text { days' income) } \\
\text { and lost } 22 \text { days (MK } 1197 \text { or USD 16) from work while } \\
\text { accessing a TB diagnosis. For the non-poor, the total costs } \\
\text { amounted to } 129 \% \text { of total monthly income, or } 184 \% \text { after food } \\
\text { expenditures. For the poor, this cost rose to } 248 \% \text { of monthly } \\
\text { income or } 574 \% \text { after food. The actual cost of diagnosis is high, } \\
\text { averaging USD } 29 \text { or } 41 \text { days income }\end{array}$ \\
\hline Lönnroth et al. [46] & Myanmar & Interviews + routine data & $\begin{array}{l}\text { Patients belonging to lower socio-economic groups incurred on } \\
\text { average costs equivalent to } 68 \% \text { of annual per capital household } \\
\text { income, with a median of } 28 \% \text {. However, } 83 \% \text { of all costs were } \\
\text { incurred before starting treatment in the franchise, while } \\
\text { 'shopping' for care. During treatment in the franchise, the cost of } \\
\text { care was relatively low, corresponding to a median proportion of } \\
\text { annual per capital income of } 3 \% \text { for people from lower socio- } \\
\text { economic groups }\end{array}$ \\
\hline Needham et al. [29] & Urban Zambia & $\begin{array}{l}\text { In-depth interviews } \\
\quad(n=202)\end{array}$ & $\begin{array}{l}\text { Patients incurred a mean total cost equivalent to } 127 \% \text { of their } \\
\text { mean monthly income (USD 59) in seeking a diagnosis; direct } \\
\text { expenditures represented } 60 \% \text { of this cost. Patients lost an } \\
\text { average of } 18 \text { working days prior to diagnosis. Caregivers } \\
\text { incurred costs equivalent to } 31 \% \text { of the mean monthly income } \\
\text { (USD 15) }\end{array}$ \\
\hline Needham et al. [29] & Zambia & $\begin{array}{l}\text { Semi-structured patient } \\
\text { interviews }(n=202)\end{array}$ & $\begin{array}{l}\text { Within a resource-poor setting, TB patients face financial } \\
\text { constraints and unrecognized costs associated with their illness. } \\
\text { Travel distances and related transportation costs create a } \\
\text { significant burden on patients. In addition, 'special food' } \\
\text { expenditures add to their financial constraints }\end{array}$ \\
\hline Pantoja et al. [47] & $\begin{array}{l}\text { Bangalore City, } \\
\text { India }\end{array}$ & Interviews $N=1,138$ & $\begin{array}{l}\text { The average cost incurred by patients before treatment in the } \\
\text { Revised National TB Control Programme (RNTCP) was USD } \\
145 \text {, and during treatment it was USD } 21 \text {. Costs as a proportion } \\
\text { of annual household income per capita were } 53 \% \text { for people } \\
\text { from low standard of living households and } 41 \% \text { for those from } \\
\text { other households. Costs during treatment faced by patients } \\
\text { treated outside the RNTCP were USD } 127\end{array}$ \\
\hline Mauch et al. [4] & $\begin{array}{l}\text { Ghana, Vietnam and } \\
\text { Dominican } \\
\text { Republic }\end{array}$ & $\begin{array}{l}\text { A standard questionnaire } \\
\text { was used and adapted to } \\
\text { each country. Ghana } \\
N=135 ; \text { Vietnam } \\
N=258 ; \text { Dominican } \\
\text { Republic } N=150\end{array}$ & $\begin{array}{l}\text { A substantial percentage of patients had to stop working due to TB } \\
\text { (Ghana: } 70 \% \text {, Vietnam: } 27 \% \text {, Dominican Republic: } 60 \%) \text {. } \\
\text { Many sold property to address the increased cost burden (Ghana: } \\
37 \% \text {, Vietnam: } 5 \% \text {, Dominican Republic: } 19 \% \text { ) or borrowed } \\
\text { money (Ghana: } 47 \% \text {, Vietnam: } 17 \% \text {, Dominican Republic: } \\
45 \% \text { ). The mean total patient costs were as follows: } \\
\text { Ghana: } \$ 538 \text {, of which } \$ 145 \text { direct, } \$ 393 \text { indirect } \\
\text { Vietnam: } \$ 1,021 \text {, of which } \$ 165 \text { direct, } \$ 856 \text { indirect } \\
\text { Dominican Republic: } \$ 1,268 \text {, of which } \$ 148 \text { direct, } \$ 1,120 \\
\text { indirect }\end{array}$ \\
\hline Rajeswari et al. [16] & India & $\begin{array}{l}\text { Focus group discussions } \\
\text { and interviews ( } n=304 \\
\text { patients, } n=17 \text { focus } \\
\text { groups) }\end{array}$ & $\begin{array}{l}\text { Mean direct cost was Rs } 2,052 /- \text {, indirect RS } 3,934 /- \text {, and total cost } \\
\text { was Rs } 5,986 / \text { - (USD 171). Mean number of work days lost was } \\
83 \text { (with } 48 \text { days before treatment and } 35 \text { days during treatment) } \\
\text { and mean debts totalled Rs } 2,079 /- \text {. } \\
\text { ** Proportion of various costs in relation to annual family income } \\
\text { was } 13 \% \text { for direct costs, } 26 \% \text { for indirect costs, } 40 \% \text { for total } \\
\text { cost and } 14 \% \text { for debts. }\end{array}$ \\
\hline
\end{tabular}


Table 3 continued

\begin{tabular}{|c|c|c|c|}
\hline & Setting & Design & Key findings on direct and indirect costs \\
\hline Vassall et al. [48] & Ethiopia & $\begin{array}{l}\text { Structured questionnaire }+ \\
\text { interviews }+ \text { review of } \\
\text { medical records } N=184\end{array}$ & $\begin{array}{l}\text { Patient costs were found to be substantial compared to income } \\
\text { levels. Pre-treatment costs were } 35 \% \text { of annual household } \\
\text { income for TB patients (with no HIV), } 33 \% \text { for those with TB } \\
\text { and HIV and } 40 \% \text { for those with HIV (with no TB). Pre- } \\
\text { treatment direct costs were particularly significant. Patient costs } \\
\text { during treatment for TB range between } 49 \% \text { and } 71 \% \text { of annual } \\
\text { household income. Patient costs in the first year of ART were } \\
21 \% \text { of annual household income. Costs fell as treatment } \\
\text { progressed. }\end{array}$ \\
\hline Wyss et al. [49] & $\begin{array}{l}\text { Dar es Salaam, } \\
\text { Tanzania }\end{array}$ & Survey $(n=191)$ & $\begin{array}{l}\text { With treatment periods of } 8-12 \text { months, extrapolated average } \\
\text { costs of a period of illness to patients and their families were as } \\
\text { follows: USD } 2 \text { for examination and laboratory costs; USD } \\
17-50 \text { for consultation and drugs; less than USD } 1 \text { for } \\
\text { hospitalization and USD } 13-20 \text { for transport. The analysis } \\
\text { revealed high costs due to inability to work, ranging from USD } \\
154-1,384 \text {. }\end{array}$ \\
\hline
\end{tabular}

Russell [2] summarizes a number of the difficulties in comparing cost of illness studies (including TB studies) due to the use of different definitions and methods to quantify costs and notes the general failure of studies to include the less quantifiable costs linked with suffering, grief or social exclusion due to illness

impacts the coping strategies ${ }^{8}$ that the household must adopt (Table 4). Successful coping strategies help ensure that the individual accesses a timely diagnosis of TB and initiates and completes treatment without leading to irreversible negative consequences for either the patient or other members of the household. Negative coping strategies fail to preserve assets and reduce production and income levels, thereby increasing the risk of collapse for the household or deepening impoverishment.

The financing options for both poor and non-poor patients usually include out-of-pocket expenditures, bank loans, borrowing from other sources such as relatives, sale of assets, change of expenditure patterns and labour substitution. Kamolratanakul et al. [32] found that for patients with incomes below the poverty line, expenditures for medical treatment, transportation and food increased significantly, while expenditure for clothing and tobacco/alcohol was significantly reduced. Changes in consumption patterns to finance illness costs are often negative and counterproductive, for example, when expenditures on food and other essential goods are reduced. Reduced food expenditures, for example, often reduce the quality of diet for both the patient and household members. The reduced micronutrient intake may weaken their immune system and increase household members' risk of developing TB themselves [33]. For pregnant and lactating women and young children, it may affect birth and growth and development outcomes.

The costs involved in getting diagnosed and initiating and adhering to treatment may be prohibitive and may

\footnotetext{
${ }^{8}$ Coping strategies are defined as actions that aim to manage the costs of an event or process, such as illness, that threatens the welfare of one or more members of the household [2].
}

discourage some from obtaining a diagnosis or starting treatment. And for those that start treatment, it is crucial to examine what financing methods are used and how these influence the sustainability of livelihoods in the longer term.

The success of coping strategies generally depends on two interrelated factors, namely, the ability of the household to cope with the shock and the type, severity and duration of illness [2]. The coping ability of the household is based on its portfolio of assets, such as physical and financial capital (tangible assets) and education or human capital and social resources (intangible assets). Social resources are the social networks, such as kin and friendship networks, links to influential contacts and membership in community organizations, on which claims can be made to access other resources, such as financial and other support. Many authors have shown that in resource-poor contexts these networks are one of the most important resources for households to secure funds to pay for treatment. Russell [2] cites ample evidence, which indicates that the poorest have the weakest social networks and are less likely to be assisted through inter-household community support mechanisms [28, 34, 35].

Mauch et al. [4] showed that while many patients take out loans, the percentage of those who pay high interest varies by country. One can argue that the ability to take out loans with no or low interest may represent a proxy indicator for the strength of a patient's social network.

In the case of tuberculosis, where individuals are subject to stigmatisation and social exclusion that further undermines access to social networks, the coping ability of the household is directly undermined. Further, the chronic or long-term nature of tuberculosis imposes high costs over 
Table 4 Key findings on methods of financing from selected TB studies

\begin{tabular}{|c|c|c|c|}
\hline & Setting & Design & Key findings on financing \\
\hline Jackson et al. [27] & Rural China & $\begin{array}{l}\text { Case-control and case follow-up } \\
\text { study }(n=160 \text { cases, } n=320 \\
\text { controls) }\end{array}$ & $\begin{array}{l}66 \% \text { of TB households borrowed from relatives and } \\
\text { friends; } 8.3 \% \text { borrowed from banks; } 45 \% \text { sold } \\
\text { productive assets (e.g. tractors, draft animals) }\end{array}$ \\
\hline $\begin{array}{l}\text { Kamolratanakul } \\
\text { et al. [20] }\end{array}$ & Thailand & $\begin{array}{l}\text { Cross-sectional survey }(n=673 \\
\text { total, } n=153 \text { below poverty } \\
\text { line) }\end{array}$ & $\begin{array}{l}\text { Expenditures were most frequently financed from } \\
\text { household savings or transfer payments from } \\
\text { community members and relatives; however, } 11.8 \% \text { of } \\
\text { patient households took out bank loans, and } 15.9 \% \text { sold } \\
\text { part of their property }\end{array}$ \\
\hline Mauch et al. [4] & $\begin{array}{l}\text { Ghana, Vietnam, } \\
\text { Dominican Republic }\end{array}$ & $\begin{array}{l}\text { A standard questionnaire was } \\
\text { used and adapted to each } \\
\text { country. } \\
\text { Ghana } N=135 \text {; Vietnam } \\
\quad \begin{array}{l}N=258 ; \text { Dominican Republic } \\
N=150\end{array}\end{array}$ & $\begin{array}{l}\text { Patients who sold property: } 37 \% \text { (Ghana), } 5 \% \\
\text { (Vietnam), } 19 \% \text { (Dom. Rep.) } \\
\text { Patients who took out loans: } 47 \% \text { (Ghana), } 17 \% \\
\text { (Vietnam), } 45 \% \text { (Dom. Rep.). } 37 \% \text { (i.e. over } 80 \% \text { of } \\
\text { those taking out loans) in the Dom. Republic paid over } \\
10 \% \text { interest on their loans. } \\
\text { Reversely, while } 67 \% \text { of patients in Ghana had some } \\
\text { health insurance, only } 48 \% \text { did in Vietnam and } 32 \% \text { in } \\
\text { Dom. Republic. When asked whether they had received } \\
\text { reimbursements, } 4 \% \text { of Ghanaian patients did, while } \\
\text { this figure stood at } 26 \% \text { for Vietnam and } 3 \% \text { for Dom. } \\
\text { Republic }\end{array}$ \\
\hline Needham et al. [29] & Urban Zambia & In-depth interviews $(n=202)$ & $\begin{array}{l}61 \% \text { of patients reported receiving financial assistance } \\
\text { from outside their household }\end{array}$ \\
\hline Rajeswari et al. [16] & India & $\begin{array}{l}\text { Focus group discussions and } \\
\text { interviews ( } n=304 \text { patients, } \\
n=17 \text { focus groups) }\end{array}$ & $\begin{array}{l}67 \% \text { of rural and } 75 \% \text { of urban patients borrowed money } \\
\text { on account of the disease; the average debt incurred due } \\
\text { to the disease was Rs. 1,405 for rural and Rs. } 2,762 \text { for } \\
\text { urban patients. }\end{array}$ \\
\hline
\end{tabular}

time because regular treatment is required and the sick are not able to work. In addition, the cost of food increases in general due to higher needs, but especially during hospitalization when both the patient and the accompanying household member have to purchase food. Russell [2] found that the high costs of TB triggered either not seeking or abandoning treatment or risky asset strategies (such as selling property or land) to raise substantial amounts of money. In short, TB cost burdens are high and may lead to strategies that reduce assets, increase household debt and increase vulnerability to future shocks [2]. There are therefore real concerns about the long-term impact of these coping strategies.

\section{Discussion}

The socio-economic burden of tuberculosis disease as well as the cost burden of its treatment has been well documented in a variety of contexts, especially resource-limited settings. The key socio-economic consequences of tuberculosis include stigma, social isolation, increased out-ofpocket expenditures for medical and non-medical costs and reduced income. These negative consequences of TB adversely affect both the well-being of the individual and associated family members and close contacts, but also the control of tuberculosis as a public health problem itself. Delayed diagnosis and initiation of treatment, suboptimal adherence and failure to complete treatment can lead to new infections among close contacts and the development of drug resistant cases which then require much more complicated and expensive treatment regimens.

The direct and indirect economic costs of tuberculosis can represent a significant, sometimes catastrophic, proportion of the monthly or annual income of a poor patient. Since the poor must already devote a significant proportion of their monthly expenditure to food, the combined loss of come and higher disease-induced expenditures can quickly lead to further impoverishment, often accompanied by mounting debt and the sale of productive household or farm assets.

Efforts to mitigate the burden for the patient are, therefore, essential so that poor patients can afford to seek a TB diagnosis, initiate and adhere to treatment and to enhance the quality of life/coping of the individual and his family. Marginalized groups such as refugees, labour migrants, internally displaced people, the homeless, slum dwellers, substance abusers, prison populations and others would seem particularly poorly prepared to face the often catastrophic consequences of TB without external help. HIV, malnutrition and smoking are the biggest risk factors for TB and are often disproportionately high in those groups. With HIV being one of the most prominent risk 
factors for TB, especially in many high prevalence countries in Sub-Saharan Africa, the socio-economic burden of TB often compounds that of HIV.

There are two ways to reduce treatment costs for the patient, reducing the direct and indirect costs of seeking a diagnosis and obtaining treatment, as well as income transfers to offset some of the costs incurred. While it is important to recognize the importance of the former which limits the cost burden that needs to be mitigated, it is also crucial to dedicate efforts and resources to the latter. Social transfers are implemented in many different contexts. They include both broader social safety nets which are meant to shield people from falling below the poverty line or mitigating poverty and more specific mechanisms conceived for one or several of a number of diseases including TB and HIV. They usually take the form of cash, a voucher (for food) or food and are typically finite in duration. They can be conditional upon attending regular medical appointments. Often that conditionality is automatic if the transfer (or entitlement voucher) is given at the Health Center. The amount is typically meant to compensate for the temporarily disease-induced increased expenditures and/or loss of income.

In the absence of direct transfers which provide a temporary safety net for those affected, the poorest and least well-connected households will inevitably pay the price with poorer health outcomes such as delayed diagnosis and inadequate adherence to treatment. For a disease such as TB, such outcomes can have high public health costs, thereby affecting society at large. As a result, many authors argue that finite social transfers can lead to better disease outcomes, which may make them good investments from a societal perspective.

Social transfers can potentially support TB patients and their treatment in a number of ways. First, these transfers promote health-seeking behaviour enabling the individual to get a diagnosis and to adhere to treatment for the duration of the illness by reducing some of the financial barriers to diagnosis and treatment. Evidence shows that even in developed countries, food insecurity correlates with worse health outcomes for HIV [36] and TB [33, 37-39]. Patients who otherwise would not be likely to seek a diagnosis, would fail to pick up the test result or who would be likely to discontinue treatment prematurely due to the associated direct medical and non-medical costs are encouraged and enabled to pursue treatment because some of the expenses are covered or offset by the value of the transfer. While a study in Malawi has shown that small cash transfers can significantly increase the likelihood of people returning to pick up their HIV test result [40], a transfer may be easier to implement and justify once a patient is diagnosed and needs treatment for a period of at least 6 months.
Second, food, cash or voucher transfers also help to protect minimum food expenditures (and other essential household expenditures); this is particularly important for the TB patient given the crucial role that good nutrition plays not only in recovery from the disease, but also in reducing the risk of developing active disease for close contacts which has been shown to be associated with malnutrition [1]. Poor households typically spend large amounts of their income on basic food expenditure, typically between 50 and $80 \%$ [41]. When poor households spend a large percentage of their income on basic food expenditures, the onset of disease can oblige them to reduce overall food expenditure at household level. An income transfer allows households to maintain this food expenditure instead of reducing it. When given as food or in the form of vouchers which are to be redeemed for specific food products at local stores, the programme implementer can have a more direct influence on the affected household's diet. For example, it can ensure that diets include micronutrient-fortified products that may or may not be available in local markets. Also one should take into account that when a patient receives a specialized food to address malnutrition, this also constitutes an income transfer.

Third, social transfers reduce the need to accumulate debt or to sell productive assets by reducing the level of borrowing or indebtedness needed to manage the costs of the disease. They ensure the longer-term sustainability of the household and its economy. This, in turn, increases the resilience of the household and its ability to withstand future economic shocks that may or may not be related to illness.

Fourth, food, cash or voucher transfers help reduce negative impacts on other members of the household, especially young children and school-age children. By lessening financial pressure on the household, transfers help parents keep their children in school and prevent them from dropping out and seeking employment to support the family. The nutritional status and health of vulnerable young children are therefore also protected to some extent by helping ensure minimum levels of food expenditure. Here again choosing food or vouchers as a transfer may be more cost effective than a cash transfer, if and when the food products chosen are nutritionally adequate to meet the needs of the patient and other household members, which depend not only on physiological status, but also on age and gender. Alternatively, when giving cash, a programme implementer relies on the household making cost optimal choices and on nutritious food being locally available and affordable. In many low-income contexts, specialized nutritious foods for young children are either not available or high-priced to target the wealthy. In many countries, especially those where rice is the staple food, 
micronutrient-fortified foods are not readily available with the exception of a few foods that are fortified with just one micronutrient (such as iodized salt, fortified margarine or vegetable oil). The poor often do not have sufficient income to afford diets which meet their micronutrient needs. Linear programming analysis shows that some of the limiting nutrients come from animal source foods which are often prohibitively expensive for the poor [42]. As a result the poor tend to have inadequate diets and households which live close to the poverty line and face a shock such as sudden disease are likely to further reduce their dietary diversity, and hence its nutritional quality, entering a vicious cycle where disease and malnutrition compound each other.

The choice of whether the transfer takes the form of food, cash or vouchers as a mitigation and patient support strategy depends on the context, including the needs of the patient, overall food availability, the functioning of local food markets, the availability and affordability of adequate products and the poverty and food security status of TBaffected households. While such an income transfer mitigates the impact of the disease, separate interventions may be required to assist malnourished TB patients in recovering from undernutrition. While the former can take the form of food, cash or vouchers depending on context, the latter will always be food- or voucher based to ensure adequate nutritional content. In the latter case, the voucher would be tied to a specific food basket.

Based on the papers reviewed, we recommend that mitigating transfers should be more routinely included in TB treatment and care programmes. Many governments have already taken steps in that direction in both high and middle-income environments. Examples include Brazil, the Philippines and Peru. The World Food Programme supports many low-income country governments to do so in order to break the vicious cycle where poverty breeds disease, which in turn begets more poverty.

While such programmes do represent a cost, the expenditure needs to be seen as an investment that allows people to return to productive lives sooner and prevents them from engaging in coping strategies that trap them in poverty.

A 2008 review included fifteen cash transfer schemes and seven microfinance interventions in a TB context. A positive impact on household food security was documented in respectively eight of nine and three of five cash transfer and microfinance interventions. Improved health care access was documented respectively in 10 of 12 cash transfer and four of five microfinance interventions [43]. No study, however, analysed the cost effectiveness in detail. Was the benefit worth the investment? What is the cost?

A 2010 study commissioned by UNAIDS [44] found that the full programme cost of supporting a TB-affected household for 270 days was on average across countries \$168. Data were obtained from World Food Programme (WFP) HIV and/or TB programmes in 42 low- and middleincome countries for 2008 and 2009. ${ }^{9}$ While few authors have studied cost effectiveness in detail, a South African study has estimated the medical per patient cost of diagnosing and treating TB at $\$ 26,392$ for XDR-TB, four times greater than MDR-TB $(\$ 6,772)$, and 103 times greater than drug-sensitive TB (\$257) [45]. So if faster diagnosis can prevent the spread of TB to close contacts and effective treatment can reduce the risk of drug resistance, the investment may pay off very quickly in terms of public health gains and avoided health expenditure.

The WFP recommends different models, dependent on context and in-line with national policies and in support of specific government programmes. In the Republic of Congo for example, malnourished TB patients can benefit from a broader safety net that targets the urban poor. Households receive a monetary transfer of $\$ 40$ for a period of up to one year if their household income is less than $\$ 60$ a month. If a malnourished TB patient lives in the household, they also receive a monthly ration of specialized ready-to-use or fortified blended food. The monthly cost for the specialized food is an additional $\$ 9$ approximately. While this programme includes TB (and HIV) patients in a broader social protection scheme, in Swaziland the Government uses Global Fund funding to setup a separate programme which provides a food ration of micronutrient fortified corn soy blend to malnourished HIV and TB patients only, while also giving their households a food basket composed of maizemeal, pulses and oil, which may in the future be replaced by a voucher or a cash transfer. Total monthly programme cost is approximately $\$ 52$ per beneficiary household. Beneficiaries exit the programme when their anthropometry shows for a second month in a row that they are no longer malnourished. This happens typically after six months, which means total programme cost is close to $\$ 300$ per household. It is higher than in the above-mentioned UNAIDS study [44] because the household receives a full food basket.

These two examples already show a variety of policy and programme considerations that shape any effort to mitigate the social consequences of TB or other diseases. Is the programme disease-based or poverty-based? If it is

\footnotetext{
${ }^{9}$ Standardized food packages were created to meet the nutritional needs of each client group. The ration design reflects not only those food products most commonly used and distributed in established WFP programmes, but also followed the World Health Organization (WHO)/Food and Agriculture Organization (FAO) and WFP recommendations providing $10-12 \%$ of total energy from protein and $17 \%$ of energy from fat and offer on average $80-85 \%$ of the total kilocalories required daily for the index client. A small ration for the household is assumed to reduce sharing $(300 \mathrm{kcal}$ each for four additional household members).
} 
disease-based, does it target TB specifically or also includes HIV or other chronic or disabling conditions? Does it include an explicit nutrition component as part of the transfer? Is it using cash, vouchers or food or a combination? What are entry and exit criteria?

Undoubtedly a variety of models can be effective in reducing the social and economic burden of tuberculosis, and its negative consequences, in different contexts. Despite the dearth of research which measures the impact of socio-economic support and its cost effectiveness, many such programmes are implemented across the world. While more research is needed to provide policy makers and public health officials more guidance on how to navigate the many decisions they need to make, it is evident many countries have decided it is good policy to mitigate the socio-economic consequences of disease. More studies should more specifically look at the return on the investment governments make in terms of not only earlier and more sustained return to productivity, improved health outcomes for household members of the index patient, but also broader public health outcomes. One of the reasons, why so little research exists certainly is potential complexity. While benefits for patients and their household members could also be assessed through randomized controlled trials, it is important to understand the shortcomings of those methods. Attribution can become very challenging when looking at broader public health outcomes, while the effectiveness and efficiency of socio-economic transfers is very context-specific, so it may be difficult to generalize from randomized controlled trials. Instead, good programme impact pathway research and thorough and iterative programme design and evaluations may at times be more insightful.

\section{References}

1. Lönnroth K, Castro KG, Chakaya JM, Chauhan LS, Floyd K, Glaziou P, Raviglione MC. Tuberculosis control and elimination 2010-50: cure, care, and social development. Lancet. 2010; 375(9728):1814-29.

2. Russell S. The economic burden of illness for households in developing countries: a review of studies focusing on malaria, tuberculosis, and human immunodeficiency virus/acquired immunodeficiency syndrome. Am J Trop Med Hyg. 2004;71(2):147-55.

3. Prescott N, Pradhan M (eds) Coping with catastrophic health shocks. Washington DC; 1999. pp. 24-5.

4. Mauch V, F Bonsu, Gyapong M, Awini E, Suarez P, Marcelino B, Melgen RE, Lönnroth $\mathrm{K}$ et al. Free tuberculosis diagnosis and treatment are not enough: patient cost evidence from three continents. Int J Tuberc Lung Dis. 2013;17(3):381-7 doi: 105588/ijtld120 368. http://www.ncbi.nlm.nih.gov/pubmed/23407227. Accessed on 16 Oct 2013.

5. Ranson MK. Reduction of catastrophic health care expenditures by a community-based health insurance scheme in Gujarat, India: current experiences and challenges. Bull World Health Organ
2002;80(8):613-21. Available from: http://www.ncbi.nlm.nih. gov/pubmed/12219151. Accessed on 27 Aug 2002.

6. Xu K, Evans DB, Carrin G, Aguilar-Rivera AM. Designing Health Financing Systems to Reduce Catastrophic Health Expenditure. apps.who.int. Geneva; 2005. http://apps.who.int/iris/bitstream/ 10665/70005/1/WHO_EIP_HSF_PB_05.02_eng.pdf. Accessed on 16 Oct 2013.

7. Xu K, Evans DB, Kawabata K, Zeramdini R, Klavus J, Murray CJL. Understanding household catastrophic health expenditures: a multi-country analysis. In: Murray CJL, Evans DB, editors. Health systems performance assessment: debates, methods and empiricism. Geneva; 2003. pp. 565-72. http://www.who.int/health_ financing/documents/hspa_chp42-hh_cata.pdf.

8. EuropeAid. Addressing undernutrition in external assistance-An integrated approach through sectors and aid modalities. 2011. pp. 1-100. http://europa.eu. Accessed on 26 Sep 2012.

9. Chilton M, Chyatte M, Breaux J. The negative effects of poverty and food insecurity on child development. Indian J Med Res. 2007;126:262-72.

10. Isanaka S, Mora-Plazas M, Lopez-Arana S, Baylin A, Villamor E. Food insecurity is highly prevalent and predicts underweight but not overweight in adults and school children from Bogota, Colombia. J Nutr. 2007;137:2747-55.

11. Unit NHA. 2012 Standard Project Report Analysis: HIV and TB Programmes. WFP Internal Data. 2013; pp. 1-17.

12. Gelaw M, Genebo T, Dejene A, Lemma E, Eyob G. Attitude and social consequences of tuberculosis in Addis Ababa, Ethiopia. East Afr Med J. 2001;78(7):382-8.

13. Liefooghe R, Michiels N, Habib S, Moran MB, De Muynck A. Perception and social consequences of tuberculosis: a focus group study of tuberculosis patients in Sialkot, Pakistan. Soc Sci Med. 1995;41(12):1685-92.

14. Long NH, Johansson E, Diwan VK, Winkvist A. Fear and social isolation as consequences of tuberculosis in VietNam: a gender analysis. Health Policy. 2001;2001(58):69-81.

15. Sengupta S, Pungrassami P, Balthip Q, Strauss R, Kasetjaroen Y, Chongsuvivatwong V, Van Rie A. Social impact of tuberculosis in southern Thailand: views from patients, care providers and the community. Int J Tuberc Lung Dis. 2006;10(9):1008-12.

16. Rajeswari R, Balasubramanian R, Muniyandi M, Geetharamani S, Thresa X, Venkatesan P. Socio-economic impact of tuberculosis on patients and family in India. Int $\mathrm{J}$ Tuberc Lung Dis. 1999;3(10):869-77.

17. Black RE, Victora CG, Walker SP, Bhutta ZA, Christian P, de Onis M, Ezzati M, Group ATMACNS, et al. Maternal and Child Nutrition 1. Lancet. 2013;1-25.

18. Barnum HN. Cost savings from alternative treatments for tuberculosis. Soc Sci Med. 1986;23(9):847-50.

19. Chunhaswasdikul B, Kamolratanakul P, Jittinandana A, Tangcharoensathien V, Kuptawintu S, Pantumabamrung P. Antituberculosis programs in Thailand: a cost analysis. Southeast Asian J Trop Med Public Health. 1992;23(2):195-9.

20. Kamolratanakul P, Chunhaswasdikul B, Jittinandana A, Tangcharoensathien V, Udomrati N, Akksilp S. Cost-effectiveness analysis of three short-course anti-tuberculosis programmes compared with a standard regimen in Thailand. J Clin Epidemiol. 1993;46(7):631-6.

21. Joesoef MR, Remington PL, Jiptoherijanto PT. Epidemiological model and cost-effectiveness analysis of tuberculosis treatment programmes in Indonesia. Int J Epidemiol. 1989;18(1):174-9.

22. Murray CJ, DeJonghe E, Chum HJ, Nyangulu DS, Salomao A, Styblo K. Cost effectiveness of chemotherapy for pulmonary tuberculosis in three sub-Saharan African countries. Lancet. 1991;338(8778):1305-8.

23. Burman WJ, Dalton CB, Cohn DL, Butler JR, Reves RR. A costeffectiveness analysis of directly observed therapy vs. self- 
administered therapy for treatment of tuberculosis. Chest. 1997;112(1):63-70.

24. Saunderson PR. An economic evaluation of alternative programme designs for tuberculosis control in rural Uganda. Soc Sci Med. 1995;40(9):1203-12.

25. Berman P, Kendall C, Bhattacharyya K. The household production of health: integrating social science perspectives on microlevel health determinants. Soc Sci Med. 1994;38(2):205-15.

26. Sauerborn R, Ibrango I, Nougtara A, Borchert M, Hien M, Benzler J, Koob E, Diesfeld HJ. The economic costs of illness for rural households in Burkina Faso. Trop Med Parasitol. 1995; 46(1):54-60.

27. Jackson S, Sleigh AC, Wang GJ, Liu XL. Poverty and the economic effects of TB in rural China. Int $\mathbf{J}$ Tuberc Lung Dis. 2006;10(10):1104-10.

28. Mann G, Squire S, Nhlema B, Luhanga T, Salaniponi F, Kemp J. Expanding DOTS; Time for cost-effective diagnostic strategies for the poorest in Malawi. Montreal; 2002.

29. Needham DM, Godfrey-Faussett P, Foster SD. Barriers to tuberculosis control in urban Zambia: the economic impact and burden on patients prior to diagnosis. I Int $\mathbf{J}$ Tuberc Lung Dis. 1998;2(10):811-7.

30. Lönnroth K, Tran TU, Thuong LM, Quy HT, Diwan V. Can I afford free treatment?: Perceived consequences of health care provider choices among people with tuberculosis in Ho Chi Minh City, Vietnam. Soc Sci Med. 2001;52(6):935-48.

31. Kemp JR, Mann G, Simwaka BN, Salaniponi FM, Squire SB. Can Malawi's poor afford free tuberculosis services? Patient and household costs associated with a tuberculosis diagnosis in Lilongwe. Bull World Health Organ. 2007;85(8):580-5.

32. Kamolratanakul P, Sawert H, Kongsin S, Lertmaharit S, Sriwongsa J, Na-Songkhla S, Wangmane S, Jittimanee S, Payanandana V. Economic impact of tuberculosis at the household level. Int J Tuberc Lung Dis. 1999;3(7):596-602.

33. Semba RD, Darnton-Hill I, de Pee S. Addressing tuberculosis in the context of malnutrition and HIV coinfection. Food Nutr Bull. 2010;31(4):345-64.

34. Sauerborn R, Adams A, Hien M. Household strategies to cope with the economic costs of illness. Soc Sci Med. 1996;43(3): 291-301.

35. Russell S. Ability to pay for health care: concepts and evidence. Health Policy Plan. 1996;11(3):219-37.

36. Weiser SD, Hatcher A, Frongillo EA, Guzman D, Riley ED, Bangsberg DR, Kushel MB. Food insecurity is associated with greater acute care utilization among HIV-infected homeless and marginally housed individuals in San Francisco. J Gen Intern Med. 2012;28(1):91-8.

37. Lönnroth K, Jaramillo E, Williams BG, Dye C, Raviglione M. Drivers of tuberculosis epidemics: the role of risk factors and social determinants. Social Sci Med. 2009;68(12):2240-6.
38. Lönnroth K, Williams BG, Cegielski P, Dye C. A consistent loglinear relationship between tuberculosis incidence and body mass index. Int J Epidemiol. 2010;39(1):149-55.

39. Tverdal A. Body mass index and incidence of tuberculosis. Eur $\mathbf{J}$ Respir Dis 1986;69(5):355-62. http://www.ncbi.nlm.nih.gov/ pubmed/3792471.

40. Thornton RL. The demand for, and impact of learning HIV status. Am Econ Rev. 2008;98(5):1829-63.

41. Brinkman HJ, de Pee S, Sanogo I, Subran L, Bloem MW. High food prices and the global financial crisis have reduced access to nutritious food and worsened nutritional status and health. J Nutr. 2009;140(1):153S-61S

42. Baldi G, Martini E, Catharina M, Muslimatun S, Fahmida U, Jahari AB, Hardinsyah, Frega R, Geniez P, Grede N, Minarto, Bloem MW, de Pee S. Cost of the Diet (CoD) tool: First results from Indonesia and applications for policy discussion on food and nutrition security. Food Nutr Bull. 2013;34(2):35-42.

43. Boccia D, Hargreaves J, Lönnroth K, Jaramillo E, Weiss J, Uplekar M, Porter JDH, Evans CA. Cash transfer and microfinance interventions for tuberculosis control: review of the impact evidence and policy implications. Int J Tuberc Lung Dis. 2011; 15(6):37-49.

44. Center for Global Health GWU, WFP, UNAIDS. Cost of providing nutritional support for: People living with HIV, adults receiving TB treatment, orphans and vulnerable children and pregnant women. CGH/WFP/UNAIDS. 2010;1-60. http://www. unaids.org/en/media/unaids/contentassets/dataimport/pub/base document/2010/20100506_cost_nutritional_support_en.pdf.

45. Pooran A, Pieterson E, Davids M, Theron G, Dheda K. What is the cost of diagnosis and management of drug resistant tuberculosis in South Africa? Caylà JA, editor. PLoS ONE. 2013;8(1): e54587.

46. Lönnroth K, Aung T, Maung W, Kluge H, Uplekar M. Social franchising of TB care through private GPs in Myanmar: an assessment of treatment results, access, equity and financial protection. Health Policy Plan. 2007;22(3):156-66.

47. Pantoja A, Floyd K, Unnikrishnan KP, Jitendra R, Joesoef MR, Lal SS, Uplekar M, Chauhan LS, Kumar P, Sahu S, Wares F, Lönnroth $\mathrm{K}$. Economic evaluation of public-private mix for tuberculosis care and control, India. Part I. Socio-economic profile and costs among tuberculosis patients. Int J Tuberc Lung Dis. 2009;13(6):698-704.

48. Vassall A, Seme A, Compernolle P, Meheus F. Patient costs of accessing collaborative tuberculosis and human immunodeficiency virus interventions in Ethiopia. Int $\mathbf{J}$ Tuberc Lung Dis. 2010;14(5):604-10.

49. Wyss K, Kilima P, Lorenz N. Costs of tuberculosis for households and health care providers in Dar es Salaam. Tanzania. Trop Med Int Health. 2001;6(1):60-8. 